\title{
Beings of a Feather: Learning About the Lives of Birds with Amazonian Peoples
}

\author{
Kevin Jernigan ${ }^{1 *}$ \\ ${ }^{1}$ Ethnobotany Program, University of Alaska, Fairbanks, AK, USA. \\ *kjernigan@alaska.edu
}

\begin{abstract}
This article is a memoir of the author's fieldwork experiences studying traditional knowledge of bird species in the Peruvian Amazon. It describes his growth as a researcher, in light of the practical and methodological challenges of carrying out this kind of work. It also relates how the author's thinking has evolved on questions of current theoretical interest in ethnobiology. The first section outlines how the author came to be interested in this topic while pursuing an ethnobotanical dissertation project. Next, the discussion follows his work with the indigenous Aguaruna and lquito peoples, learning about and documenting their understandings of the nesting, foraging and reproductive behavior of local avian species. On one hand, he found that local people provided details of these behaviors that match, in many ways, the counts of academic ornithologists. However, local interpretations of why these behaviors take place are often framed by some very different assumptions. The author uses Victor Toledo's tripartite framework of kosmos (overarching belief systems), corpus (cognitive categories), and praxis (set of practices) to discuss similarities and differences in Aguaruna, lquito, and academic ornithology. He also discusses his progression of views on the topic of perspectivism and eventual preference for a theoretical framework favoring a polyontological approach to understanding Amazonian ethnoecology.
\end{abstract}

Received June 15, 2016

OPEN ठACCESS

Accepted November 8, 2016

DOI 10.14237/ebl.7.2.2016.726

Keywords Ethnoecology, Perspectivism, Peruvian Amazon, Aguaruna, Iquito

Copyright (c) 2016 by the author(s); licensee Society of Ethnobiology. This is an open-access article distributed under the terms of the Creative Commons Attribution-NonCommercial 4.0 International Public License (https://creativecommons.org/licenses/by-nc/4.0), which permits non-commercial use, distribution, and reproduction in any medium, provided the original author and source are credited.

\section{From Ethnobotany to Ethnoornithology}

I first became interested in the field of ethnoornithology by an indirect route. I am not much of a birder, but I do find birds to be beautiful and fascinating animals. And, even though I take some pride in having observed species such as the Royal Sunangel (Heliangelus regalis) and the Andean Cock-of-the-rock (Rupicola peruvianus) in their natural habitat, I do not keep a life list or brag about such things in polite company. Plants are my first love and it is through them that I became interested in how Amazonian peoples understand avian behavior and the complex relationships birds have with other organisms.

My dissertation work studied how the Aguaruna of the Peruvian department of Amazonas recognize and identify local tree species. I found that they use a wide variety of morphological clues for distinguishing trees, including bark odor, sap color, leaf shape, and many others (Jernigan 2006b). But there are important ecological clues as well. For example, local people also recognize trees by noting which animal species use them for food and shelter. I first became aware of such interspecies relationships in a rather unfortunate way, when I brushed against the gallery forest tree tagkana (Triplaris surinamensis) and was stung by the Pseudomyrmex triplarinus ants that live symbiotically in the trunk.

My appreciation for the extensive knowledge that Aguaruna people have about bird-tree interactions came in a less dramatic way, but ultimately made an even deeper impression. My thesis fieldwork in 2004 alternated between walks in the forest with community members to observe and learn about trees firsthand and sitting on rainy days under thatched roofs with elders who named and described the trees they knew from memory. I was humbled when the most knowledgeable of them, brothers Shugki and Ashambai, gave over 200 names and then apologized for not being able to remember the rest. And indeed, they could describe these species in minute detail, from the 
appearance of the flowers and fruit to the odor and texture of the bark. For certain local trees, they listed dozens of bird species that feed on the fruits. For example, many kinds of toucans, cracids, and doves favor the aromatic fruits of tinchi, a general term for the Lauraceae, while smaller birds such as manakins and tanagers feed off the berries of tseek (Miconia ternatifolia in the Melastomataceae). I wondered whether this knowledge was based more on direct observation or on generalization of behavior across categories. How do they weigh, for example, the size of the bird, its habitat, and its foraging level in the canopy when deciding what it is likely to eat? When I returned home, I forgot about these questions, as I faced the trials and tribulations of transcribing notes, analyzing data, and writing and defending the dreaded dissertation.

I completed my Ph.D. in anthropology from the University of Georgia in 2006, and, suddenly, there were more things in life to think about than how people identify trees. I remembered my curiosity about Aguaruna knowledge of bird diet and developed a research proposal to document this and other aspects of Aguaruna ethnoornithology. Happily, the National Science Foundation provided funding to carry out this new project. I was eager to go back and speak with my friends and mentors in communities where I worked. I thought fondly, for example, of an elder named Kintambai. During my dissertation work, when I came to his village for the second time, after being away for several months, he wondered aloud whether I had failed my studies the first time and had to start over. Perhaps, I thought to myself, his worries about my academic achievement would be magnified when I arrived yet again.

\section{Learning about Birds with the Aguaruna and Iquito}

I assembled a team of local collaborators in Peru, and we planned to begin work with Aguaruna villages in June, 2009. The day after I arrived in Lima, however, I heard some news that would change my plans, at least for a time. A state of emergency had been declared and a conflict was escalating between the government of Peru's president Alan Garcia, and the country's indigenous peoples over a new law that would grant international companies easier access to petroleum, minerals, and logging on land adjacent to native communities. The Aguaruna people were particularly vocal in their opposition to the new law. There was a violent confrontation with governmental security forces and dozens from each side died. I called my friends in the region to see how they were doing and, luckily, none were hurt. Not surprisingly, they recommended that I wait before coming to do work.

I traveled to the rainforest city of Iquitos to meet with some collaborators and discuss our plans. There, I learned of a documentation project that linguists Christine Beier and Lev Michael, then, at the University of Texas, Austin, were carrying out with some of the last speakers of the critically endangered Iquito language (see Beier and Michael 2002). The 20 or so speakers, all over 50 years old, live mainly in the village of San Antonio de Pintoyacu, in the upper Nanay region, some $60 \mathrm{~km}$ from the city of Iquitos. I asked Christine and Lev if they could use an ethnobotanist in their project, and they welcomed me to join them. In addition to our ethnobotanical work, we also recorded knowledge of diet and other ecological information for a few dozen of the most common local bird species.

One particularly fascinating bit of traditional ecological knowledge (TEK) that Iquito participants generously shared with us involves the species cusacuuni ácuta (Oryctanthus alveolatus in the Loranthaceae)-pigeon's ayabuasca. Elder Ema Llona explained that the Ruddy Pigeon (Patagioenas subvinacea) consumes the berries of this parasitic species and then becomes intoxicated, just as people do when they take the divinatory preparation ayahuasca. She even imitated how the birds sing for me to record.

This explanation of animal behavior by analogy to human customs underscores a very important concept in Amazonian ethnology and beyond. Perspectivism (Viveiros de Castro 1998) posits that animals and people share the same cultural and social reality, while differing in their physical bodies. The idea has gained much popularity and has been very influential in research in the Amazon and beyond (Holbraad and Willerslev 2007, Kohn 2007, Shepard 2014) And, indeed, my own work with Amazonian peoples would show me many more instances that fit this ontological framework.

Several months later, when the situation in Amazonas had calmed down, our team went to begin work in Aguaruna communities. We arrived first in the villages of Wichim and Wawas, where people already knew and trusted me from my dissertation fieldwork. They welcomed us there, but we heard that the situation was still touchy in some places. They said 
there were villages where residents did not even let in veterinarians to vaccinate their animals due to fear that the government might be sending agents to root out people involved in the previous conflicts.

The first task of the research, before we could ask detailed questions about birds' behavior, was simply to determine which species local people recognize and how they consider them to be related. So, we began the work with elders by doing the simple and useful task of freelisting. The Aguaruna word pishak is the closest equivalent to the general category of 'bird' in English. We sat down with elders and asked them to name as many pishak as they could remember. This allowed us to have a list of local bird names to use as a springboard for many other questions, for example, about foraging and reproductive behavior. Next, we asked elders to tell us which birds are kumpaji companions, a concept that groups together species considered to be related. We found that local people recognize such natural groupings as parrots, toucans, tinamous, and woodpeckers, based on commonalities of appearance and behavior (Jernigan and Dauphine 2008).

We also observed avian species in extensive field excursions with study participants around the villages. This, along with the work of Brent Berlin (1992) and colleagues (Boster et al. 1986), helped us understand how local bird names map onto scientific species. The issue is non-trivial, as there is not always a one-to-one correspondence between Linnaean and local categories. For example, all of the five local woodcreeper species in genus Xiphorynchus are subsumed under the single Aguaruna name kuintam. Although people recognize that there are different kinds, this diversity is not visually striking (Berlin 1992) or culturally significant (Hunn 1982) enough to recognize with individual Aguaruna names.

Another important part of understanding Aguaruna ornithology was observing how they use and interact with birds on a daily basis. Their favorite game are the tinamous and cracids, including currasows, guans, and chachalacas. However, even very small birds such as manakins and tanagers can be hunted and eaten. This fact was driven home for me in a powerful way, when an Aguaruna friend and field assistant, stopped to eat the entire eggs from a hummingbird nest on one of our excursions.

Bird species with brightly-colored feathers, such as toucans and oropendolas, are especially valued for decorating the tawas, a traditional crown worn by men.
At times, whole birds are put on these for decoration. Others, such as the chuwag-Turkey Vulture (Cathartes aura) — can be killed to make a hunting charm. Some birds' vocalizations are considered to have divinatory power. The nocturnal calls of some owl species, for example, can be omens of death of a close relative. Other species are kept as pets, particularly parrots (Figure 1), toucans, woodpeckers, tanagers, cracids, and oropendolas. This is only a small sampling meant to give some idea of the breadth of Aguaruna uses.

After finishing work in Wichim and Wawas, we were able, with the help of local indigenous organizations, to visit a few communities where none of us had worked before. These included the villages of Yangunga and Tunants, on the upper Marañon. The first thing that happened when we arrived in these new places_-and, indeed, in any Aguaruna village-is that people called a public meeting to discuss the proposed work. Such meetings are an essential part of Aguaruna society and allow people to voice their questions and concerns about issues that come up. I learned in my earlier dissertation research (Jernigan 2006a) the importance of participation and transpar-

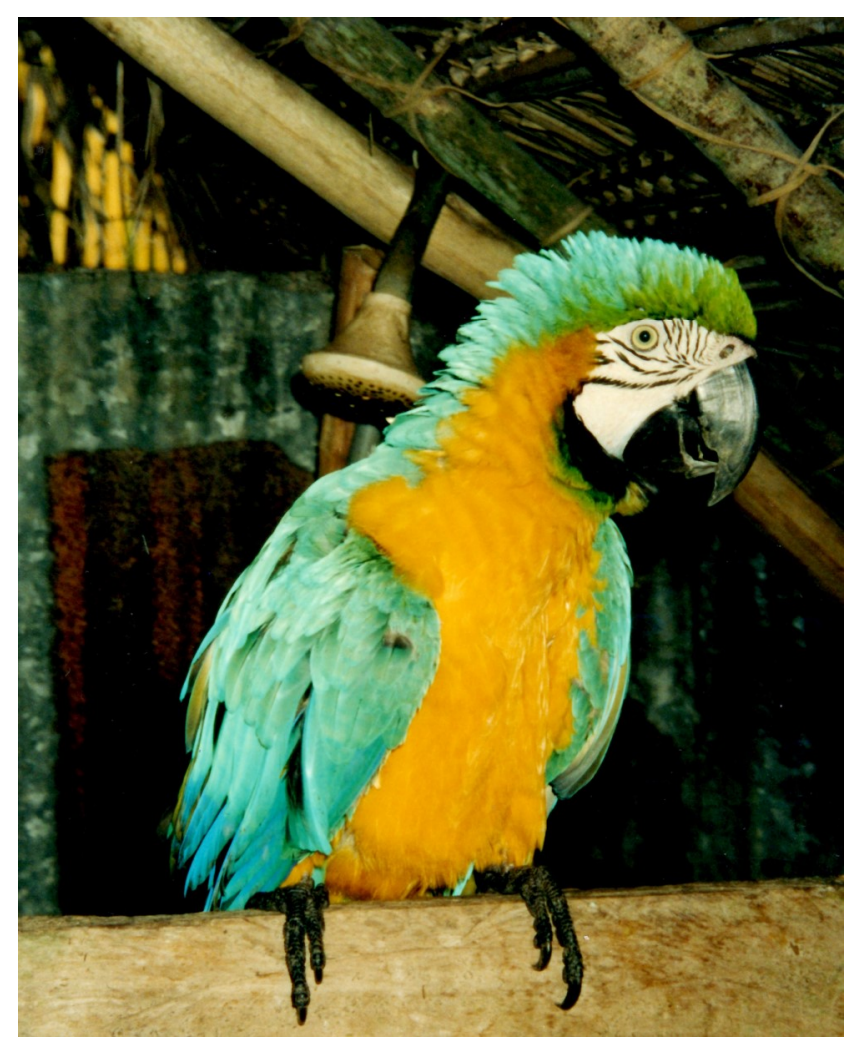

Figure 1 Pet Blue-and-yellow macaw, Village of Santa Maria de Nieva, 2003. Photo by Kevin Jernigan. 
ency, when I made a mistake that almost cost me the trust of another village. The elected leader-apu—of that village had approached me asking for some money that he said would be used to everyone's benefit. I later found out that he pocketed the funds. Luckily, a local friend and collaborator convinced community members that I was not to blame and had learned my lesson. So, I kept this in mind at the meetings in Yangunga and Tunants. Happily, both communities accepted our work, and we learned many interesting and valuable things there.

\section{Amazonian and Academic Ornithology}

One of the first things I noticed, working with the Aguaruna and Iquito, is the many areas in which their knowledge of bird behavior and ecology agrees with the observations of academic ornithologists. This agreement should not be too surprising, considering that both the Aguaruna and academic researchers gain much understanding and insight from extensive observation of birds in their natural habitats. Of course, the manner of, and reasons for, making observations are not always the same.

Aguaruna elders' accounts of nesting and reproductive behavior would be quite familiar to an academic ornithologist. For example, Wilson Sakamaju Tupika in the upper Marañón community of Yangunga described brood parasitism of species such as tsantsentse - Giant Cowbird (Molothrus oriayvorus) — saying that, instead of making its own nest to care for its young, it simply lays its eggs in the nests of oropendolas (Schulenberg et al. 2007).

Local Amazonian people were able to describe, in detail, the particular fruits, invertebrates and other organisms that form the diets of bird species in their area. And, indeed, the author has already discussed elsewhere (Jernigan and Dauphine 2008) how their knowledge on this subject closely matches that of academic ornithologists. But this TEK goes beyond merely naming the preferred diet of individual species. It touches on more complex ecological relationships. For example, Aguaruna elders knew that toucans and aracaris play an important role in seed dispersal, but that many parrot species, such as tuwish (Pionus menstruus), are seed predators. Similarly, Iquito elders described how the siamuri (Black Caracara) eats ticks off the skin of ungulates such as tapirs.

There are, however, some notable differences in academic and Amazonian understandings of bird behavior. For instance, Aguaruna cosmology recog- nizes the existence of beings that the scientific worldview does not. These could be understood as spirits, visions or legends, although, to the Aguaruna, they are simply another part of the natural world. One example involves the puwi, an omnivorous parrot that is said to live in a remote location, four days journey on foot from one of our study sites. Nestor Reategui, an Aguaruna friend and collaborator, described how he had traveled to the site and saw trees completely denuded of leaves. People living nearby told him that the birds feed at night and are quite capable of eating animals and humans as well. When I mentioned the puwi to academic ornithologists who work in Peru, they were very skeptical. I must admit that I tend to feel the same way. However, if a specimen ever does turn up, it would not be the first time that academics learned a new bird species already well-known to the Aguaruna. In one such case, an ornithologist recognized a new tanager species when a missionary gave him an Aguaruna tawas-decorated crown. It contained a whole inchituch, and was given the Latinized name Wetmorethraupis sterrhopteron (Lowery and O’Neill 1964).

So how can we best conceptualize the relationship between Aguaruna and academic ornithology? Victor Toledo (2002) has called for organizing TEK into three distinct but interrelated domains. These are: the corpus, knowledge and classificatory systems; praxis, the set of practices of a given culture, and kosmos, the overarching worldview including spiritual and moral ideas.

The corpus of Aguaruna and academic ornithology line up fairly well. Aside from spiritual beings, the two systems often agree on the what of bird taxonomy and behavior. The question of $w h y$ birds behave as they do is another story. That is where Aguaruna and academic science really diverge.

The Aguaruna tend to view the reasons for avian behavior through a perspectivist lens. In other words, they interpret complex ecological relationships in terms of their own social and cultural reality. For example, some birds in their area such as kunchauthe White-plumed Antbird (Pithys albifrons) follow swarms of army ants to prey on insects and other small animals flushed out by the advancing column. According to academic ornithologists, those birds are simply taking advantage of the situation to forage. However, the Aguaruna say they are actually directing the ants, that the ants are like their dogs. 
One broad similarity is that history plays an important role in both academic and Aguaruna understandings of bird behavior. However, in the former case, it is evolutionary history, while in the latter it is augmatbau - traditional stories. One important angmatbau tells how birds once had human form. After winning a protracted struggle against a giant crab monster named Unkaju, they held a celebration and transformed themselves into their current shapes. Each reveler assumed a form corresponding to his appearance at the time. One man named Achayap, for example, wearing a bright yellow tawas-crown-changed into the Golden-headed Manakin (Pipra erythrocephala).

Another example to illustrate these different views of history involves lekking behavior. Aguaruna collaborators told us how some local birds, for example, tashijim - White-bearded Manakin (Manacus manacus) —and ugkum-Amazonian Umbrellabird (Cephalopterus ornatus) —engage in dances. They even gave detailed descriptions of the stereotypical movements of the species in question, matching those that academic ornithologists have published (Schulenberg et al. 2007; Sick 1993). However, rather than viewing this behavior as a competition between males for female mate selection, the Aguaruna say that the birds were once people who enjoyed dancing and celebrating. Once transformed into birds, they continued throwing parties just like they used to. This goes a long way toward explaining Aguaruna perspectivism. Birds act like people because they essentially are people.

\section{A Few Final Thoughts}

When I returned home from Peru, I was left to review my notes and to try to reconcile some fundamentally different ways of interpreting Amazonian views of bird ecology. On one hand, many observations of the details of avian behavior fit well into a naturalistic view that would seem familiar to an academic ornithologist. On the other hand, one finds, digging deeper, that Amazonian explanations for why birds act as they do relies on a much different view where birds and other animals share a social reality with humans (Viveiros de Castro 1998).

Indeed, the situation would only become more complicated in the following years as I became familiar with yet a third possible framework for understanding Amazonian ornithology. I submitted an abstract based on my Amazonian work to the 2013 meeting of the American Anthropological Association meeting in Chicago. When I received my notice of acceptance, I found that my paper was placed within the theme of multispecies ethnography. This new way of looking at human-animal relationships draws heavily on social theory (Kirksey and Helmreich 2010, Latour 2009). Like perspectivisn, multispecies ethnography recognizes the agency of non-human animals, but it places more emphasis on the complex relationships, or entanglements, between various types of persons (Kohn 2007, Shepard 2014).

Learning about this new trend in anthropology brought to my mind a discussion I had with my Aguaruna field assistant Gregorio Reategui. He explained how local people interpret a characteristic vocalization of the species bakantau-Buckley's Forest -Falcon (Micrastur buckleyi). Aguaruna hear the words "ikagmak tae, ikagmak tae," a warning that someone in the village will commit adultery. When I asked Gregorio why the bird would wish to do this, he explained that it was possessed by a malevolent spirit called an imanch who wants to sow discord. So, this in not a story about animals who share the same social reality as humans. Rather, it is about complex and unequal relationships between intelligent beings with not only differing bodies, but also differing motivations.

As I pondered the many things I learned during my work, I realized there were more examples that did not fit neatly into a perspectivist framework. One genre of Aguaruna anen-magical songs-enlists the help of particular bird species to help in human romantic relationships. For instance, a woman can entreat the antpitta puampua (Grallaria sp.) to find her far away husband and sing him a sad song that will make him homesick. A man who is sleeping with another man's wife can use another anen to invoke the power of the ukukui - the Ornate Hawk-eagle (Spizaetus ornatus) to scratch his rival if he should notice the infidelity. So rather than living in a parallel society, birds' lives are often closely intertwined with human lives.

I have not had the opportunity to return to Peru since the project on bird ecology ended in 2010. In the meantime, I took a job at the University of Alaska and my attention has since been focused greatly on the ethnobotany of the U.S. and Russian sides of the Bering Strait. However, I do intend to return someday soon to the Peruvian Amazon to continue researching people's complex understandings of the natural world. When I do, I will go with an appreciation for the 
difficulty in fitting their knowledge into a single epistemological framework. Rather, I will draw happily from naturalistic, perspectivist, and multispecies approaches when each is appropriate. Perhaps the most important thing I have learned from my research experiences is the realization that one approach cannot explain everything.

\section{Acknowledgments}

I would like to thank Glenn Shepard and Brent Berlin for many helpful comments and much encouragement in the work. Thanks also to four anonymous reviewers for their many helpful suggestions. Most of all, I thank the people of the communities Wichim, Wawas, Tunants, Cachiaco, Kayamas, Yangunga, and Nuevo Belice, where this research took place. Tercero Lirio Gregorio Reategui and Nestor Reategui were very helpful in their assistance with coordinating this research.

\section{Declarations}

Permissions: Permissions to conduct this research were obtained from the University of Alaska Institutional Review Board, the Ministry of Agriculture in Peru and from the native communities of Wichim, Wawas, Tunants, Cachiaco, Kayamas, Yangunga, and Nuevo Belice in Peru. Following the wishes of local communities and individuals who participated in this study, this paper does not use pseudonyms for local people. This is in keeping with the ethical principal of giving credit where it is due to the elders who have made the work described here possible.

Sources of Funding: This study was funded by a National Science Foundation grant (0314289).

Conflicts of Interest. None declared.

\section{References Cited}

Beier, C. and L. Michael. 2002. La Condición Actual del Idioma Indígena Iquito y las Claves Factores Afectando al Proyecto de su Recuperación. Available at: http://www.cabeceras.org/

Iquito_Informe_2002.pdf. Accessed on 6/14/2016.

Berlin, B. 1992. Ethnobiological Classification: Principles of Categorization of Animals and Plants in Traditional Societies. Princeton University Press, Princeton, NJ.

Berlin B., J. S. Boster, J. P. O'Neill. 1981. The Perceptual Bases of Ethnobiological Classification: Evidence from Aguaruna Jivaro Ornithology. Journal of Ethnobiology 1:95-108.
Davies, C. W. N., R. Barnes, S. H. M. Butchard, M. Fernandez and N. Seddon. 1997. The Conservation Status of the Cordillera de Colán. Bird Conservation International 7:181-195. DOI:10.1017/ s0959270900001490

Holbraad, M., and R. Willerslev. 2007. Transcendental Perspectivism: Anonymous Viewpoints from Inner Asia. Inner Asia 9:329-345. DOI: 10.1163/146481707793646511.

Hunn, E. 1982. The Utilitarian Factor in Folk Biological Classification. American Antbropologist 84:830-847. DOI: 10.1525/aa.1982.84.4.02a00070.

Jernigan, K. 2006. An Ethnobiological Exploration of Sensory and Ecological Aspects of Tree Identification among the Aguaruna Jívaro. Unpublished Ph.D. dissertation, Department of Anthropology, University of Georgia, Athens. Available at: https:// getd.libs.uga.edu/pdfs/

jernigan_kevin_a_200605_phd.pdf. Accessed on $11 / 3 / 2016$.

Jernigan, K. 2006. An Ethnobotanical Investigation of Tree Identification by the Aguaruna Jívaro of the Peruvian Amazon. Journal of Ethnobiology 26:107-125. DOI:10.2993/0278-0771(2006)26[107:aeioti] 2.0.co;2.

Jernigan, K. and N. Dauphine. 2008. Aguaruna Knowledge of Bird Foraging Ecology: A Comparison with Scientific Data. Ethnobotany Research and Applications. 6:93-106. DOI:10.17348/era.6.0.93106.

Kirksey, S. and S. Helmreich. 2010. The Emergence of Multispecies Ethnography. Cultural Anthropology 25:545-576. DOI: $10.1111 /$ j.15481360.2010.01069.x.

Kohn, E. O. 2005. Runa Realism: Upper Amazonian Attitudes to Nature Knowing. Ethnos 70:171-196. DOI: $10.1080 / 00141840500141162$.

Latour, B. 2009. Perspectivism:'Type'or 'Bomb'?”. Anthropology Today 25:1-2. DOI: 10.1111/j.14678322.2009.00652.x.

Lowery, G. H. and J. P. O’Neill. 1964. A New Genus and Species of Tanager from Peru. The Auk 81:125131. DOI:10.2307/4082763.

Schulenberg, T. S., D. F. Stolz, D. R. Lang, J. P. O'Neill, and T. A. Parker. 2007. Birds of Peru Princeton University Press, Princeton, NJ. 
Shepard, Glenn. 2014. "Old and in the Way: Jaguar

Transformation in Matisgenka." In IX Sesquiannual Conference of the Society for the Anthropology of Lowland South America (SALSA) Gothenburg, Sweden, June, 2629. Available at: https://

www.academia.edu/15538299/

Old_and_in_the_way_Jaguar_transformation_in_M atsigenka. Accessed on 11/3/2016.

Sick, H. 1993. Birds in Brazil: A Natural History. Princeton University Press, Princeton, NJ.
Toledo, V. M. 2002. Ethnoecology: A Conceptual Framework for the Study of Indigenous Knowledge of Nature. In Ethnobiology and Biocultural Diversity, edited by J. R. Stepp, F. S. Wyndham, and R. K. Zarger, pp. 511-522. University of Georgia Press, Athens, GA.

Viveiros de Castro, E. 1998. Cosmological Deixis and Amerindian Perspectivism. Journal of the Royal Anthropological Institute 4:469-488. DOI: 10.2307/3034157. 